https://doi.org/10.48009/1_iis_2006_305-309

\title{
PREDICTORS OF STUDENT SUCCESS IN A PROJECT MANAGEMENT COURSE
}

\author{
Manouchehr Tabatabaei, Georgia Southern University, mtabata@georgiasouthern.edu \\ Han Reichgelt, Georgia Southern University, han@georgiasouthern.edu
}

\begin{abstract}
The importance of project management is increasing in Information Systems (IS) and Information Technology (IT) education. The IS model curriculum includes a course on project management, while the recently promulgated $A B E T$ CAC accreditation criteria for programs in IT state that graduates from IT programs must have the ability to assist in the creation of an effective project plan. Moreover, this interest in project management is partly driven by industry. For example, in its recurrent interviews with CIOs, the Standish group found that having an experienced project manager is now seen as one of the main factors for success in IT projects.

In a preliminary study reported last year, we found that having a project management course early in the program of study seemed to help students in subsequent heavily project-based courses. This was especially true in regard to students with a lower GPA. Given the importance of project management for student success, both after graduation and in their program of study, it is important to try to determine what factors are likely to increase student success in a project management course. In this research, we examine a number of factors, including performance in prior courses such as management and organizational behavior, statistics, and mathematics. We also examine whether there is a relationship between student success in a project management course and when students take the course in their academic programs.
\end{abstract}

Keywords: IS/IT Education, Project Management, Performance in Project Management Course

\section{INTRODUCTION}

Project Management (PM) is an important skill to acquire for Information Systems (IS) and Information Technology (IT) graduates as it is in increasing demand among employers. For example, in the 2000 version of the Standish Group Chaos report [7], CIOs ranked having an experienced project manager as the third most important success factor in IT projects, and exceeded in importance by only executive support and user involvement.
In addition, the IS 2002 Model Curriculum [4] contains a course on project management and the recently promulgated IT model curriculum also includes a substantial amount of PM related material [5]. Moreover, PM has a central place in the new proposed accreditation criteria for IS and IT that are under consideration for adoption by the Computing Accreditation Commission of ABET [1]. Thus, IT explicitly includes the ability to assist in the creation of an effective project plan among the attributes that a graduate from an IT program must possess. IS includes PM in a more indirect way in its accreditation criteria as it insists that graduates from an IS program must have an understanding of processes that support the delivery and management of information systems within a specific application environment. It is not hard to argue that this includes a basic understanding of PM techniques.

PM is also an important skill for students to develop during their course of study. Many programs rely heavily on projects in both the delivery of the material that they want their students to master and in the assessment of student success, and this trend is likely to continue [6]. As reported by Tabatabaei and Reichgelt [8], students seem to perform better in courses with a heavy project component if they have had prior exposure to PM techniques. This is particularly true for students with a lower GPA.

Given the importance of PM, it is important to determine what makes students more prepared and therefore more successful in the PM course. Since PM is closely related to management and organizational behavior, it is possible that students who have been exposed to these topics might perform better in their PM course. Furthermore, given the fact that at least certain elements of PM seem to require a certain formal ability, one would expect students enrolled in a PM course to benefit from prior courses in mathematics or statistics.

The preceding discussions suggest the following research questions:

RQ1: What are the predictors of student success in PM courses? In particular, does it matter whether students take a PM course early or late in their program of study? 
RQ2: Does a prior course in management or organizational behavior help students in PM course?

RQ3: What is the relationship between mathematics and statistics on the one hand and PM on the other?

\section{RESEARCH METHODOLOGY}

We focused on the IS and IT students enrolled at Georgia Southern University to answer the research questions. Since a PM course is required for both IS and IT majors, this yielded a reasonable size population of 157 students. We examined student performance in the PM course and we collected information on the number of hours students took prior to taking the PM course as a proxy for where in the program of study students took the course. We also examined performance of PM students in their prior courses such as management and organizational behavior, one of two statistics courses (see below), and an introductory mathematics course entitled "Survey of Calculus." In all cases, we used the final grade that a student received in a course as the only indicator of their performance in the course. In particular, we ignored possible effects of the instructor of the course, or whether the student was repeating the course.

\section{RESULTS}

Table 1 shows the performance of students in the PM course and their GPA along with the number of hours completed prior to taking the PM course.

Table 1. Performance in Project Management

\begin{tabular}{|c|c|c|}
\hline Grade & GPA & Completed Hours \\
\hline A & 3.44 & 130.91 \\
\hline B & 2.97 & 114.22 \\
\hline C & 2.68 & 116.55 \\
\hline D or F & 2.42 & 107.35 \\
\hline
\end{tabular}

Table 2 shows the performance of students in the PM course according to whether they took the class in their third year $(<90)$, fourth year $(90-120)$, or final semester $(>120)$. This table shows that students generally performed better in the PM course when they took this course later in their program of study. The result is statistically weakly significant (chi square: 11.28 , df $6, \mathrm{p}<0.1)$.
Table 2. Grade in PM Course

\begin{tabular}{|c|c|c|c|c|c|}
\hline & \multicolumn{4}{|c|}{ Grade in PM Course } & \\
\hline $\begin{array}{c}\text { Completed } \\
\text { Hours }\end{array}$ & A & B & C & $\begin{array}{c}\text { D } \\
\text { or F }\end{array}$ & Tot. \\
\hline$<90$ & 0 & 4 & 10 & 3 & 17 \\
\hline $90-120$ & 5 & 29 & 22 & 8 & 64 \\
\hline$>120$ & 13 & 25 & 29 & 6 & 72 \\
\hline TOTAL & 18 & 58 & 61 & 16 & 153 \\
\hline
\end{tabular}

Table 3 presents the performance of students in PM course after a prior course in management and organizational behavior (MOB).

Table 3. Prior exposure to Management \& Organizational Behavior Course

\begin{tabular}{|c|c|c|c|c|c|}
\hline & \multicolumn{4}{|c|}{ Grade in PM Course } & \\
\hline Grade MOB & $\mathbf{A}$ & B & $\mathbf{C}$ & D or $\mathbf{F}$ & Tot. \\
\hline $\mathrm{A}$ & 5 & 6 & 4 & & 15 \\
\hline B & 4 & 6 & 10 & 5 & 25 \\
\hline $\mathrm{C}$ & & 8 & 7 & 1 & 16 \\
\hline $\mathrm{D}$ or $\mathrm{F}$ & & & 1 & & 1 \\
\hline Not done & 10 & 38 & 37 & 11 & 96 \\
\hline Total & 19 & 58 & 59 & 17 & 157 \\
\hline
\end{tabular}

Table 3 seems to indicate that prior exposure to MOB does not help students in the PM course. Students who took a course in MOB before the PM courses did not perform any better than students who did not (chi square for entire table 15.88, df 12, ns; if we ignore students who did not take the MOB course at all, chi 13.70, df 9, ns). However, the number of students who took MOB is much smaller than those who did not take the course in this analysis and the result might be different with a larger sample size.

It is of course possible that other business courses than just MOB impact the grade in PM course. Thus, students who have completed more courses in business may perform better in a subsequent PM course. If this is the case, then IS students should perform better in PM course compared to their IT counterparts since the IS students take more business courses than the IT students.

Table 4 indicates that there is a statistically weakly significant difference in the performance of different majors (chi square 8.53, df $6, \mathrm{p}<0.1$ ). Therefore, at first sight, the results seem to indicate that students who have taken a number of business courses may perform better in the PM course. However, the data also indicates that Pre-IT students, students who are 
registered for the IT program but have not yet completed a number of foundational courses in IT, mathematics and statistics, did not perform well in the PM course. It may therefore well be the case that the correlation between major and performance in the PM course is a direct consequence of the finding reported earlier, namely that students tend to do better when they take the PM course later in their program of study.

Table 4. Effect of Major

\begin{tabular}{|c|c|c|c|c|c|c|c|c|}
\hline & $\begin{array}{c}\text { Ave } \\
\text { Adj. } \\
\text { GPA }\end{array}$ & $\begin{array}{c}\text { Ave } \\
\text { Cum } \\
\text { GPA }\end{array}$ & Hours & A & B & C & $\begin{array}{c}\text { D } \\
\text { or } \\
\text { F }\end{array}$ & Tot \\
\hline IS & 2.85 & 2.67 & 126.85 & 10 & 16 & 19 & 6 & 51 \\
\hline IT & 2.90 & 2.79 & 114.89 & 9 & 34 & 33 & 6 & 82 \\
\hline $\begin{array}{c}\text { Pre- } \\
\text { IT }\end{array}$ & 2.69 & 2.59 & 97.02 & 1 & 7 & 7 & 5 & 20 \\
\hline & & & & 20 & 57 & 59 & 17 & 123 \\
\hline
\end{tabular}

We also examined the effect of a prior statistics course. IT students are required to take an introductory statistics course, which covers descriptive statistics, probability, random variables and selected probability distributions, as well as basic statistical inference. IS students are required to take a business statistics course, which covers essentially the same topics, although with greater emphasis on the application of the concepts to a business environment. Table 5a shows the relationship between the performance in a statistics course and a PM course for IT students while table 5b shows the results for IS students. The tables indicate that both IT and IS students seem to have benefited from prior exposure to statistics in the PM course. The relationship between performance in statistics and PM is statistically weakly significant for IT students (chi square 8.90, df 9, p $<0.1$ ), as is the grade in business statistics for IS students (chi square 7.45, df $9, \mathrm{p}<0.1)$. Further, Table $5 \mathrm{c}$ provides a combination of these two tables: $5 \mathrm{a}$ and $5 \mathrm{~b}$. This table also provides a statistically weakly significant (chi square: 11.96, df 9, $\mathrm{p}<0.1$ ) result.

Table 5a. Prior Exposure of IT Students to Statistics

\begin{tabular}{|c|c|c|c|c|c|}
\hline & \multicolumn{4}{|c|}{ Grade in PM Course } & \multirow[b]{2}{*}{ Tot. } \\
\hline $\begin{array}{l}\text { Grade in } \\
\text { Intro to Stat }\end{array}$ & $\mathbf{A}$ & B & $\mathbf{C}$ & D or $\mathbf{F}$ & \\
\hline $\mathrm{A}$ & 2 & 7 & 2 & & 11 \\
\hline B & 2 & 15 & 16 & 3 & 36 \\
\hline $\mathrm{C}$ & 2 & 9 & 14 & 4 & 29 \\
\hline $\mathrm{D}$ or $\mathrm{F}$ & & 1 & 2 & 1 & 4 \\
\hline & 6 & 32 & 34 & 8 & 80 \\
\hline
\end{tabular}

Table 5b. Prior Exposure of IS Students to Statistics

\begin{tabular}{|c|c|c|c|c|c|}
\hline & \multicolumn{4}{|c|}{ Grade in PM Course } & \multirow[b]{2}{*}{ Tot. } \\
\hline $\begin{array}{l}\text { Grade in Business } \\
\text { Stat }\end{array}$ & $\mathbf{A}$ & $\mathbf{B}$ & $\mathbf{C}$ & $\mathbf{D} / \mathbf{F}$ & \\
\hline $\mathrm{A}$ & 3 & 5 & 4 & & 12 \\
\hline $\mathrm{B}$ & 3 & 6 & 4 & 1 & 14 \\
\hline $\mathrm{C}$ & 2 & 2 & 7 & 3 & 14 \\
\hline $\mathrm{D}$ or $\mathrm{F}$ & 1 & 1 & 1 & 0 & 3 \\
\hline & 9 & 14 & 16 & 4 & 43 \\
\hline
\end{tabular}

Table 5c. Prior Exposure to Statistics for all Students

\begin{tabular}{|l|r|l|r|r|r|}
\hline & \multicolumn{6}{|c|}{ Grade in PM Course } & \\
\hline $\begin{array}{l}\text { Grade in } \\
\text { Statistics }\end{array}$ & A & B & C & D/F & Tot. \\
\hline A & 5 & 12 & 6 & & 23 \\
\hline B & 5 & 21 & 20 & 4 & 50 \\
\hline C & 4 & 11 & 21 & 7 & 43 \\
\hline D or F & 1 & 2 & 3 & 1 & 7 \\
\hline & 15 & 46 & 50 & 12 & 123 \\
\hline
\end{tabular}

Table 6 represents the performance of students in a required mathematics course and its relation to the performance in the PM course. We only considered a survey of calculus course, which covers such topics as the fundamentals of differential and integral calculus, and algebraic, logarithmic and exponential functions. This table shows a higher grade in mathematics is likely to result in a higher grade in PM. There is a statistically significant relationship between the Math and PM grade (chi square: 17.9, df $9, \mathrm{p}<0.05)$.

Table 6. Prior Exposure to Mathematics

\begin{tabular}{|c|c|c|c|c|c|}
\hline & \multicolumn{4}{|c|}{ Grade in PM Course } & \multirow[b]{2}{*}{ Tot. } \\
\hline $\begin{array}{c}\text { Grade } \\
\text { in Math }\end{array}$ & $\mathbf{A}$ & B & $\mathbf{C}$ & $\begin{array}{c}\text { D or } \\
\text { F }\end{array}$ & \\
\hline $\mathrm{A}$ & 6 & 9 & 10 & 1 & 26 \\
\hline $\mathrm{B}$ & 3 & 21 & 19 & 6 & 49 \\
\hline $\mathrm{C}$ & 2 & 7 & 14 & 6 & 29 \\
\hline $\mathrm{D}$ or $\mathrm{F}$ & & & 1 & 2 & 3 \\
\hline Total & 11 & 37 & 44 & 15 & 107 \\
\hline
\end{tabular}

It is interesting to note that apparently mathematics helps students in all of their courses and not just PM. Table 7 shows the relationship between the introductory mathematics course and GPA. It is clear that a higher grade in math results in a higher GPA. Does this mean students who spend time and put in the necessary effort to learn mathematics will be at an advantage in future courses or does it mean the 
students who have the capability to understand and learn mathematics have the capability to excel in other subjects as well?

Table 7. Mathematics and GPA

\begin{tabular}{|c|c|c|}
\hline $\begin{array}{c}\text { Grade in } \\
\text { Math }\end{array}$ & GPA & Completed Hours \\
\hline A & 3.22 & 114.73 \\
\hline B & 2.85 & 109.81 \\
\hline C & 2.57 & 116.82 \\
\hline D or F & 2.21 & 85.67 \\
\hline
\end{tabular}

\section{CONCLUSIONS}

The results of this research suggest that students do benefit from prior exposure to some topics as part of preparation for the subject of PM. First, not surprisingly, the results indicate students with better GPA perform better in PM course. Second, students benefit from knowledge of mathematics and statistics. This is no surprise as basic mathematics and statistics should help students in most subjects. In addition, business courses might also be expected to help students to excel in the PM course. However, we found in this research no statistical evidence that the knowledge of management and organizational behavior courses would necessarily help students in the PM course. In general, IS students might be at an advantage in the PM course considering their business background compared to IT students, but our findings might be skewed because we also included Pre-IT students, who tend to take the PM course early in their program of study (see below). This is subject to more research in the future studies, and more research is needed before this conclusion can be drawn.

Finally, the results indicate that students who take PM course during their last year or even last semester perform better. There is a reason PM is offered at many institutions as a capstone course. Students are expected to take this course as one of their last courses to apply their knowledge of previous courses in the capstone PM course. Those who have learned the materials in the previous courses before the PM course with a higher GPA therefore can perform better. In a sense, this result is disappointing as prior research indicated that students, especially does with a lower GPA, tend to do better in heavily projectbased courses if they have completed a prior course in PM [8]. Clearly, those results would seem to indicate that students should be encouraged to take a PM course early in their program of study. Unfortunately, the data reported in this paper seem to suggest that students who follow this advice will be at a higher risk of failure (or at least sub-par performance) in a PM course.

This research has raised some issues that warrant more investigations. It is obvious that more research is needed with larger sample size and possibly at several institutions in different regions to improve external validity of the findings of this research.

The importance of team-work and project-based work is growing rapidly in virtually every industry and PM skills will continue to be important for most college graduates [6]. Therefore, careful consideration should be given on how to prepare students for the PM course in order to maximize the learning and understanding of this important subject. Future research activities should identify and investigate more predictors in successfully completing the PM course with a high level of performance. In the future different methodologies should also be adopted. For example, a survey instrument should be created to survey students before and after completion of the PM course to help determine what is needed to successfully complete the course. It would also be useful to replicate the research conducted at the undergraduate level should be replicated at the graduate level $([2,3])$.

Finally, given the seemingly contradictory facts that (a) early exposure to PM techniques seems to help students in later project-based courses [8], and (b) students tend to perform worse if they take a PM course early in their program of study, it becomes important to try to determine which aspects of a PM course help a student in later project based courses. It may well be the case that the current practice of covering all PM related skills and knowledge in a single course is not to the advantage of students. It may well be the case that certain elements of a typical PM course could and should be covered in foundational courses to give the students the opportunity to apply these skills and knowledge in subsequent courses.

\section{REFERENCES}

1. ABET (2004). Criteria for Accrediting Computing Programs. Baltimore, MD. Available at http://www.abet.org/criteria_cac.html.

2. Du, S., Johnson, R. \& Keil, M. (2004) Project management courses in IS graduate programs: What is being taught? Journal of Information Systems Education, 15, 181-188.

3. Gorgone, J. et al. (2000) MSIS 2000 Model Curriculum and Guidelines for Graduate Degree 
Programs in Information Systems, Communications of the AIS, 3(1), 1-61.

4. Gorgone, J. T., Davis, G. B., Valacich, J., Topi, H., Feinstein, D. L. \& Longenecker, H. E. J. (2002). IS 2002 model curriculum and guidelines for undergraduate degree programs in information systems, Communications of AIS. Available online http://www.acm.org/education/is2002.pdf.

5. Lunt, B. et al (2005) Computing Curricula: IT Curriculum Volume. Available at http://www.acm.org/education/curric_vols/IT_O ctober_2005.pdf
6. Reif, H. \& Mitri, M.(2005) Integration of project management components in undergraduate information systems curricula, The Journal of Computer Information Systems, 45(3), 24-31.

7. The Standish Group International (2001) Extreme Chaos. Available at http://www.standishgroup.com/sample_research/ PDFpages/extreme_chaos.pdf

8. Tabatabaei, M. \& Reichgelt, H. (2005). The effect of prior exposure to project management techniques on project-based courses. Issues in Information Systems, 6(1), 398-404. 